\title{
FREE TO CHOOSE: AN EXPERIMENTAL INVESTIGATION OF THE VALUE OF FREE CHOICE
}

\section{Lasha Lanchava}

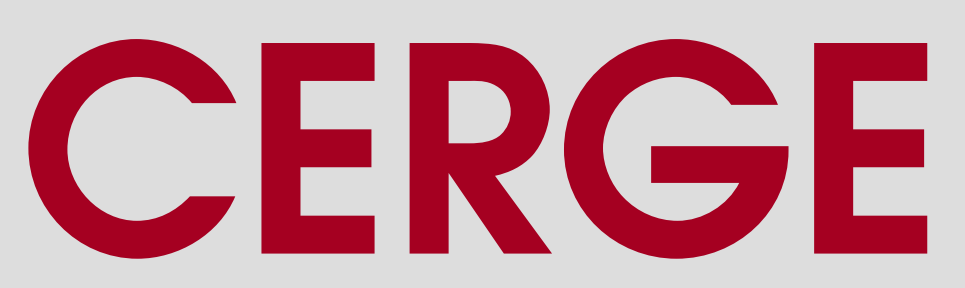




\title{
Working Paper Series 492 (ISSN 1211-3298)
}

\section{Free to Choose: An Experimental Investigation of the Value of Free Choice}

\author{
Lasha Lanchava
}

\section{CERGE-EI}

Prague, September 2013 
ISBN 978-80-7343-296-6 (Univerzita Karlova. Centrum pro ekonomický výzkum a doktorské studium)

ISBN 978-80-7344-288-0 (Národohospodářský ústav AV ČR, v.v.i.) 


\title{
Free to Choose: An Experimental Investigation of the Value of Free Choice*
}

\author{
Lasha Lanchava \\ CERGE-EI, Prague
}

\begin{abstract}
This study is the first economic experiment that tests the economic significance of the theory of psychological reactance (Brehm, 1966). For this purpose, I design an economic experiment in which subjects are asked to express their valuation of two-choice situations. In one case, subjects are given absolute freedom, whereas in another, the extent of their freedom of choice is limited. As the experimental data revealed, subjects' valuation of free and limited choice situations did not differ significantly. Thus, in the experiment, the subjects did not display signs of reactance. In the end, the potential reasons of why the subjects did not exhibit reactance are discussed. The lessons derived from this study may serve as a future guide for testing the economic significance of the reactance theory.
\end{abstract}

\begin{abstract}
Abstrakt
Tato studie je prvním ekonomickým experimentem, který testuje ekonomický význam teorie psychické reaktance (Brehm, 1966). Za tímto účelem jsem navrhl ekonomický experiment, ve kterém participanti jsou požádáni, aby vyjádřili své ocenění dvou situací obsahující rozdílné volby. $\mathrm{V}$ jednom př́padě, participantům je dána úplná svoboda, zatímco v druhém je omezen rozsah svobody jejich volby. Experimentální data ukázala, že ocenění participantů situací se svobodným a omezeným výběrem se významně nelišily. Tedy, v daném experimentu, participanti nevykazovali známky reaktance. V závěru jsou diskutovány potenciální důvody, proč participanti nevykazovali známky reaktance. Poznatky získané z této studie mohou sloužit jako východisko pro budoucí testování ekonomického významu teorie reaktance.
\end{abstract}

Kewords: psychological reactance, freedom of choice, law enforcement

JEL Classification: K0, C90, A1

\footnotetext{
* Acknowledgments: This research was supported by a grant from the Grant Agency of Charles University (GAUK) No. 583812. All opinions expressed are those of the author's and have not been endorsed by CERGE-EI or the GAUK. The financial support of the Czech Science Foundation project No. P402/12/G097 DYME Dynamic Models in Economics is acknowledged. I would like to thank Miroslav Zajicek, the director of the Laboratory of Experimental Economics (LEE) at The University of Economics, Prague (VSE). I would like to thank Peter Katuscak and Michal Bauer for providing valuable academic support. All errors remaining in this text are the responsibility of the author.

CERGE-EI, a joint workplace of Charles University and the Economics Institute of the Academy of Sciences of the Czech Republic, Politických veznu 7, 11121 Prague, Czech Republic, Lasha.Lanchava@cergeei.cz(corresponding author).
} 


\section{Introduction}

There are many real life situations (prohibitive laws, drug regulations, speed limits, etc.) where the freedom of individuals is limited. The regulation mechanisms usually send a message of authority and punishment, and they usually ignore the behavioral aspect of individual liberty. Therefore, without understanding how the essential freedom of choice in economic decision- making works, how individuals value freedom, how people react when their choice autonomy is limited, or how they face a prohibition issued by an external authority, the regulation mechanisms could be flawed from a behavioral standpoint and thus limited in their effectiveness. Moreover, understanding the economic significance of freedom could be informative for policy debates regarding the enforcement of prohibitive laws, taxation, and over the decriminalization of drug consumption.

The importance of freedom of choice for individual behavior and the consequences of its limitation are thoroughly studied in the social psychology literature originating from the ideas of J. W. Brehm (1966), who developed the theory of psychological reactance. It claims that individuals consider freedom as a naturally endowed right, and once choice autonomy is threatened or eliminated, an emotional state arises that triggers individuals to actively pursue actions that would restore their freedom of choice. In other words, individuals tend to exhibit "control aversion". There is abundant literature on psychological reactance and related experiments in social psychology ${ }^{1}$. For example, in Hammock and Brehm's (1966) experiment, experimenter threatened children's freedom to choose a certain candy bar among others by stating that it should not be chosen. Children reacted by choosing the prohibited candy bar. Worchel and Brehm (1970) explicitly prohibited subjects to take a particular position on certain theme, and they found that the subjects were more likely to adhere to the forbidden position. Brehm, Lloyd, Sensenig and Shaban (1966) found that the unavailability of music recordings increased their attractiveness. Similarly, Worchel, Lee and

\footnotetext{
${ }^{1}$ See Clee and Wiklund (1980) for an extensive review.
} 
Adewole (1975) asked subjects to rate cookies that came either scarcely or abundantly supplied. Subjects found the cookies that were scarcely supplied more desirable.

While the extent of reactance is very well studied through the lens of social psychology, little is known about its economic significance. That is, how much economic value, expressed in monetary units, would individuals sacrifice in order to preserve their sense of autonomy and freedom? Economists have devoted limited attention to the theory of psychological reactance (Verhallen, 2000; Schneider \& Enste, 2000; Tucker, 2011). However, an understanding of how the forces of psychological reactance affect economic decisionmaking could be important for several reasons. For example, conventional economic theory of crime, employing a general equilibrium analysis of crime and punishment, implies that the optimal level of fines and kind of parameters must be equal to the monetary gains that criminal offenders get from violating a certain law (Becker, 1968; Ehrlich, 1973; Polinsky \& Shavell, 2007; and others). However, as the theory of psychological reactance predicts, if criminals derive additional utility, on top of monetary gain, from violating the law in order to defend their right of freedom, then the optimal level of punishments, derived earlier in economic theory without acknowledging the phenomenon of reactance, would not be socially optimal any longer. Later arguments, however, would call for the greater acknowledgement of the human need for individual liberty to implement successfully any regulation mechanisms.

This study is the first attempt to incorporate the theory of psychological reactance into the economics of law enforcement and regulation and to test experimentally the economic significance of the theory. For this purpose, I design an economic experiment in which subjects are asked to express their valuation of two-choice situations. In one case, subjects were given absolute freedom, whereas in another, the extent of their freedom of choice is limited. However, in order to measure the extent of reactance solely, a limit is chosen so that in normal situations (i.e. without constraint), the subjects would not pursue a 
set of behaviors beyond that limit. In the experiment, the subjects did not display signs of reactance as their valuation of free and limited choice situations did not differ significantly. Potential reasons of why subjects did not exhibit reactance could be partly cognitive over exhaustion and partly due to a lack of salience of the imposed constraint. The lessons derived from this study may serve as a future guide for testing the economic significance of the reactance theory.

\section{Related Literature}

As it was noted above, the literature on psychological reactance in social psychology is extensive, and from the mainstream of these studies, a definite pattern of behavioral response to freedom limitation emerges. In particular, the literature shows that if individuals are prohibited to pursue a certain set of behaviors or substances, they exhibit excess interest in them and by all means try to commit or consume the prohibited behaviors or goods respectively as they derive additional pleasure from acting against the prohibition. A notorious example occurred in a study that banned the sale and use of phosphate containing detergents in a city in Florida in the early 1960s (Mazis, Settle, \& Leslie, 1973). Having no impact on cleaning effectiveness, phosphates were banned solely for environmental reasons. However, the city residents, unhappy with the detergent ban, stopped buying detergents (that did not contain phosphates) in the city's stores and smuggled phosphate- containing detergents from neighboring cities where their sale was legal. Compared to residents of neighboring cities, the city residents who were banned from using phosphate detergents rated them higher in terms of cleaning effectiveness (Mazis et al., 1973). Furthermore, recent record gun sales at U.S. gun trade shows, as a reaction to intensified debates over gun control in Washington, D.C. that followed the Sandy Hook massacre ${ }^{2}$, might be considered as an up-to-date example of how the forces of psychological reactance shape individual

\footnotetext{
${ }^{2}$ More information can be found at: http://www.dailymail.co.uk/news/article-2256058/Record-sales-Virginiagunfamilies-stock-weapons-Sandy-Hook-massacre.html
} 
behavior.

Despite predicting certain behavioral patterns following the prohibition, the psychological literature offers less insight into how important, from a pure economic decision- making point of view, such a behavior is (i.e. the preservation of freedom) for an individual. That is, the psychological literature does not tell us whether, when the law is enforced by means of monetary (fines) or non-monetary (imprisonment, probation) punishment, the utility gain derived from acting against the law outweighs the expected cost of potential punishment. If it is the case, then as several studies below demonstrate, law enforcement, guided by standard deterrence theory, may lack effectiveness, and in fact, it may trigger more people to commit crime.

Scientific literature related to Prohibition in the United States acknowledges that the policy was a failure, and alcohol consumption increased during the Prohibition era (Dills \& Miron, 2003; Miron \& Zwiebel, 1991; Miron \& Zwiebel, 1995). Even so, people started to drink poisonous alcohol (Darrow \& Yarros, 1927), and the death rate from alcohol poisoning achieved its peak (Coffey, 1975). There is no clear account in the literature which would explain why, against the predictions of deterrence theory, such a dramatic increase in alcohol consumption happened during the Prohibition era.

In a famous experiment, Gneezy and Rustichini (2000) show that introducing a small monetary punishment for parents who usually came late to pick up their children, in certain day care centers in Israel, doubled the number of late-comers. The authors acknowledge that standard deterrence theory is unable to explain the result. Their explanation is the following. Parents think that by paying the fine, which goes to teachers, they acquire the right to use the teachers' service: that is, to force teachers to take extra care of their children. However, a very interesting outcome occurred when the fine was abolished. The number of parent delays remained unaltered. The latter fact does not seem to be explained by the argumentation developed by Gneezy and Rustichini, a fact the authors themselves are 
aware of.

Slemrod, Blumenthal and Christian (2001) demonstrated that after an increase in the probability of being audited, the average tax compliance for high income taxpayers declined. This result is in contrast with the traditional economic theory of tax evasion (Allingam \& Sadamo, 1972; Spicer, 1974). The authors' argument is high income individuals have more opportunities to hire professional lawyers, who could legitimately reduce taxable income. Although, this line of reasoning does not explain why the taxpayers' timing for hiring professional lawyers coincided with the policy notice, nor why they did not pursue these legitimate ways of taxable income reduction earlier (before the announcement of the audit).

Although from the standard economic theory point of view the above mentioned facts may seem puzzling, the concept of reactance might be a good explanatory tool. It could be the case that because of reactance, the benefit people derived by acting against the law was more than the expected cost of punishment. Therefore, it has been observed that a new law initiative has increased unlawful behavior. If this is the case, then policymakers might need to rethink the ways of implementing regulation mechanisms. They may need to look at law enforcement from a psychological point of view in order to acknowledge the human quest for freedom and thus make enforcement mechanisms more efficient. Therefore, testing the economic significance of the theory of psychological reactance and understanding how individuals value freedom may inform policy and may also fill the gap between the theory of deterrence and punishment and existing facts. 


\section{Experimental Design \& Procedure}

\subsection{Design}

The major aim of the experimental design is to understand how non-binding constraints affect human behavior in various choice circumstances. Making sure that the constraint is non-binding helps to estimate the sole impact of control aversion on individual behavior. The experiment used constrained and unconstrained versions of the following three games: the Dictator Game (DG), the Holt and Laury lottery choice task (HL), and the simple effort game (EG).

In the unconstrained DG, the subjects are given an initial endowment and are free to send any amount to the recipient ${ }^{3}$. In the constrained dictator game, subjects are not allowed to send more than $76 \%$ to the recipient. The choice of $76 \%$ as a maximum amount subjects can send is arbitrary though it is chosen to make sure that the imposed constraint is non-binding (based on previous findings), and in a normal situation, no subject would ever consider sharing more than what is imposed by the constraint. Indeed, according to Camerer (2003), the average donations in the DGs completed so far are about $20 \%$ of the initial endowment, and normally, people do not choose to share more than $50 \%$.

In the unconstrained HL (see Table 1 in the Appendix), subjects can make choices between risky and safe options in the lottery. In the constrained HL, the subjects are not allowed to choose option B (the risky option) for more than seven times. Again, the constraint is chosen so that it is not something subjects would usually do. As Holt and Laury (2002) report, subjects choose option B 4.8 times on average with about $96 \%$ of participants never choosing the risky option more than seven times. Therefore, the choice of seven as the maximum number of times a person can choose option B is considered as a non-binding constraint with enough safety.

\footnotetext{
${ }^{3}$ The recipient in this case was the Czech Red Cross.
} 
While DG and HL involve other-regarding and risky decision-making respectively, another game is used in order to examine how control aversion affects individual behavior in much simpler individual decision situations. This effort game, EG - see Table 2 in the Appendix - consists of two tasks. In the first task, the subjects add two numbers from the range of 1 to 10 . In the second task, they count the number of zeros in a 6-digit number. For each correct answer, subjects are rewarded; however, the reward diminishes with time. The subjects have 1 minute for both tasks. In the unconstrained EG, they can freely choose how to allocate time between the two tasks. In the constrained version, they are not allowed to pursue the task of adding numbers for more than 45 seconds. Unlike DG and HL, EG has no established results in the literature, which would guide the imposing of a non-binding constraint. Although, if one looks carefully at the payoff structure, then choosing 45 seconds as the maximum time that can be spent doing the first task can be considered nonbinding. This is so because after 45 seconds, the task of adding numbers pays nothing while switching to the task of counting zeros can earn subjects considerable money. In fact, the game is designed so that subjects can maximize their earnings if they allocate time between the two tasks evenly ${ }^{4}$. Therefore, it would be fair to assume that normally, people would like to maximize their payoff; that is, after 30 seconds, the payoff-maximizing individual would prefer to switch to the counting task and earn 8 ECUs, rather than to continue with adding numbers to earn 2 ECUs and zero thereafter.

The experiment employs a strategy method in order to elicit the individuals' valuation for each of these games. Subjects are initially endowed with 100 experimental currency units (ECUs) and are asked to state their valuations of each version of the game using the Becker-DeGroot-Marschak (BDM) willingness-to-pay (WTP) elicitation

\footnotetext{
${ }^{4}$ The assumption here is the subjects' productivity does not differ too much across the two tasks. In fact, given the reward structure of the game, an individual's productivity in a counting task does not have to be less than half of his productivity in the math task. Considering the very simple nature of these two tasks, it is reasonable to think that subjects would be almost equally well-skilled in them.
} 
mechanism (Becker, DeGroot, \& Marschak, 1964). See instructions in the supplementary material section for further details. That is by paying enough, ${ }^{5}$ the subjects can earn the right to play one randomly selected game. In fact, the payoffs for each game are designed so that a rational person would be willing to pay the entire endowment (100 ECUs) to play either version of the above mentioned three games.

If in the experiment it is observed that people's WTP is higher in the unconstrained versions compared to the constrained versions, then one might argue that the price differential is driven by the individuals' demand for choice autonomy or, in other words, by control aversion. Consider DG for example: The only difference between the constrained and unconstrained versions of the game is that in the constrained version, subjects cannot send more than $76 \%$ of their endowment. According to previous literature, since sending more than even $50 \%$ of the endowment is not what subjects usually do, one can say that participants of the experiment should not mind a non-binding constraint unless they strongly dislike being controlled in any way. The same logic extends also for the other games.

\subsection{Experimental sample and procedure}

The experiment took place December 2012 in the Laboratory of Experimental Economics (LEE) in Prague. The subject pool (218 in total) mostly consisted of undergraduate students from various universities in Prague. The recruitment process was administered using the Online Recruitment System for Economic Experiments (ORSEE). The experiment was conducted in English using z-Tree software (Fischbacher, 2007). Each subject received a

\footnotetext{
${ }^{5}$ The subjects can earn the right to play the game by virtually participating in the second price auction for the game. They first have to state their WTP (in the range from 0 to 100 ECU) for the given game. Then, the computer would draw a random number $(\mathrm{N})$ from 0 to 100 , and if a participant's stated WTP is higher than the random number generated by the computer, the participant will pay N ECU—not their stated WTP —and will earn the right to play the game if selected. Otherwise, the subjects keep the initial endowment of $100 \mathrm{ECU}$.
} 
printed copy of the instructions (see the supplementary material section).

The experiment consisted of two stages. In the first stage, the subjects learned that they were endowed with 100 ECUs, and their WTP for the constrained and unconstrained versions of the described games was elicited using the BDM procedure. The order of the games was perfectly balanced across subjects. In the second stage, subjects could play one randomly selected game if they paid enough for that in the first stage and could earn additional points by playing the game. Otherwise, they kept the initial endowment of 100 ECU.

The experimental sessions lasted approximately an hour on average. At the end of the experiment, experimental points were converted to Czech crowns (CZK), and a payment process was administered. Each subject received $350 \mathrm{CZK}$ on average, which was about USD 18 according to the exchange rate at that time. For the sake of confidentiality, the person, who was in charge of payment, was not part of the research team and was not informed about the details of the experiment. Also, any personal information the cashier collected about any subject (name, surname, ID number) was not disclosed to the experimenter. This privacy policy was explained to the subjects, and they were told that neither the cashier nor the experimenter would be able to link their decisions in the experiment to their identity ${ }^{6}$.

\section{Results}

Table 1 reports the average WTP for the unconstrained and constrained versions of each game. As the reported numbers reveal, there is virtually no difference in the average WTP

\footnotetext{
${ }^{6}$ The cashier was paying experimental earnings based on the computer terminal number inscribed on the tokens subjects received at the beginning of the experiment. An experimenter, unaware of the subjects' identity, gave to the cashier a payment file, where experimental earnings were linked to the computer terminal number. Therefore, the cashier knew how much to pay the person who was holding a particular token that had the number of the terminal on it.
} 
in the unconstrained and constrained versions of either game $(p=0.79$ for DG; $p=0.41$ for HL; $p=0.91$ for EG).

Table 1

Summary Statistics:

Game Mean WTP

47.293

46.802

60.333

59.309

52.802

52.917
Std. Dev.
218

218

27.87

210

26.98

210

EG Unconstrained

EG Constrained

After a raw comparison of means, the distributions of WTP across unconstrained and constrained versions of each game were analyzed. Figures 1-3 plot the kernel density distributions of WTP. A paired-sign test showed no statistical difference in the distributions of WTP for DG $(p=0.25)$; HL $(p=0.21)$; or EG $(p=0.56)$. The Wilcoxon paired-sign rank test gives identical results. 
Figure 1

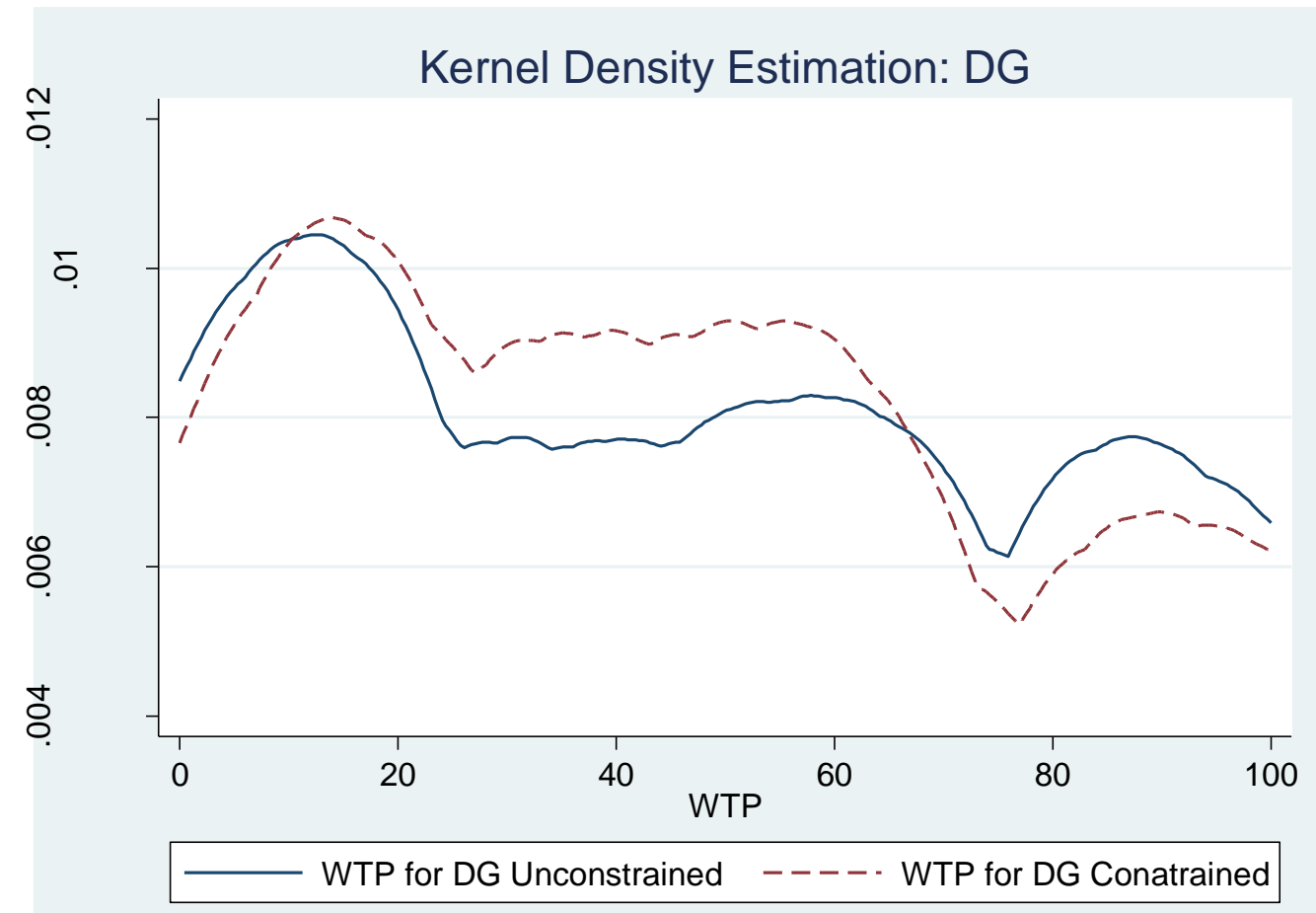

Figure 2

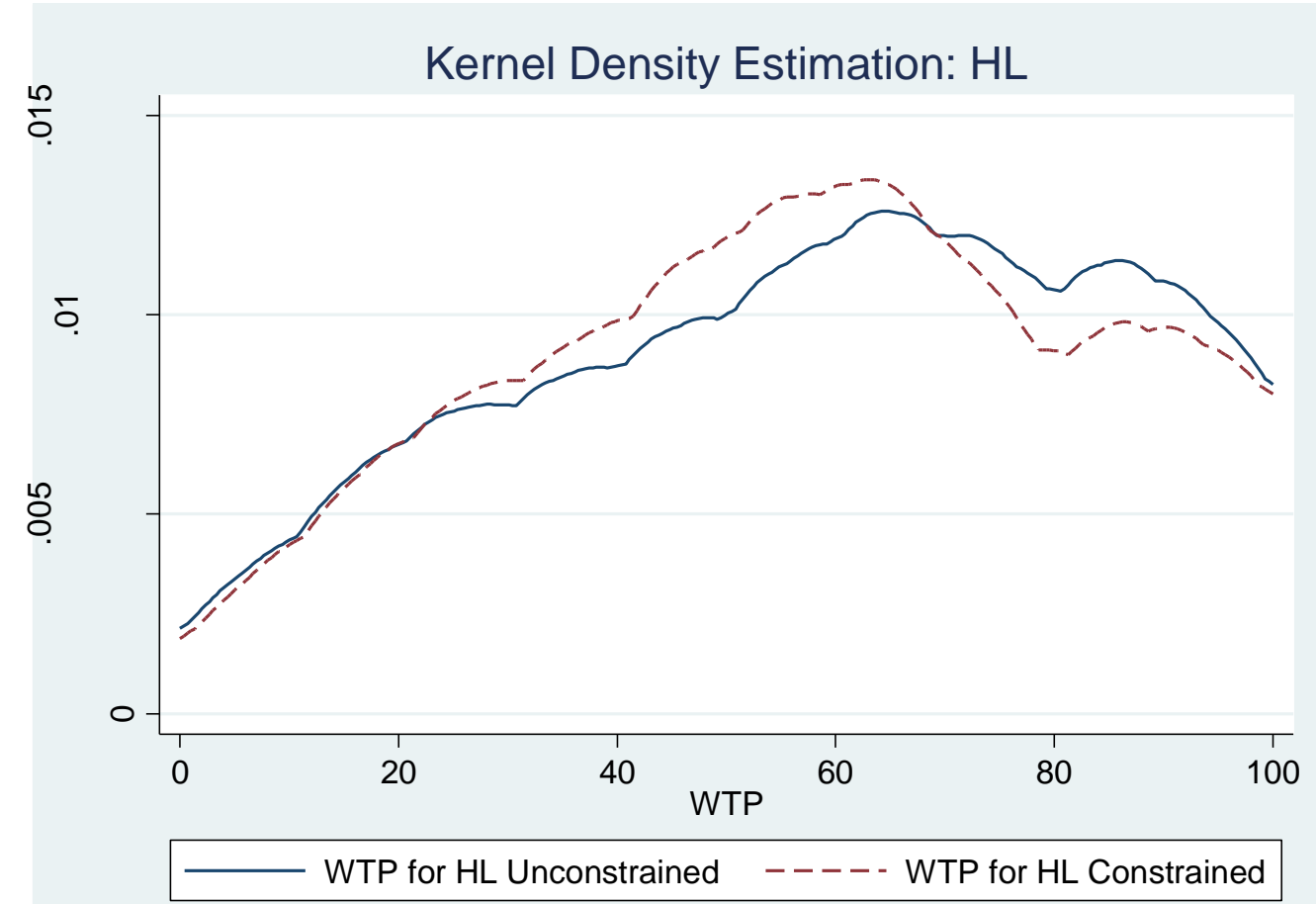


Figure 3

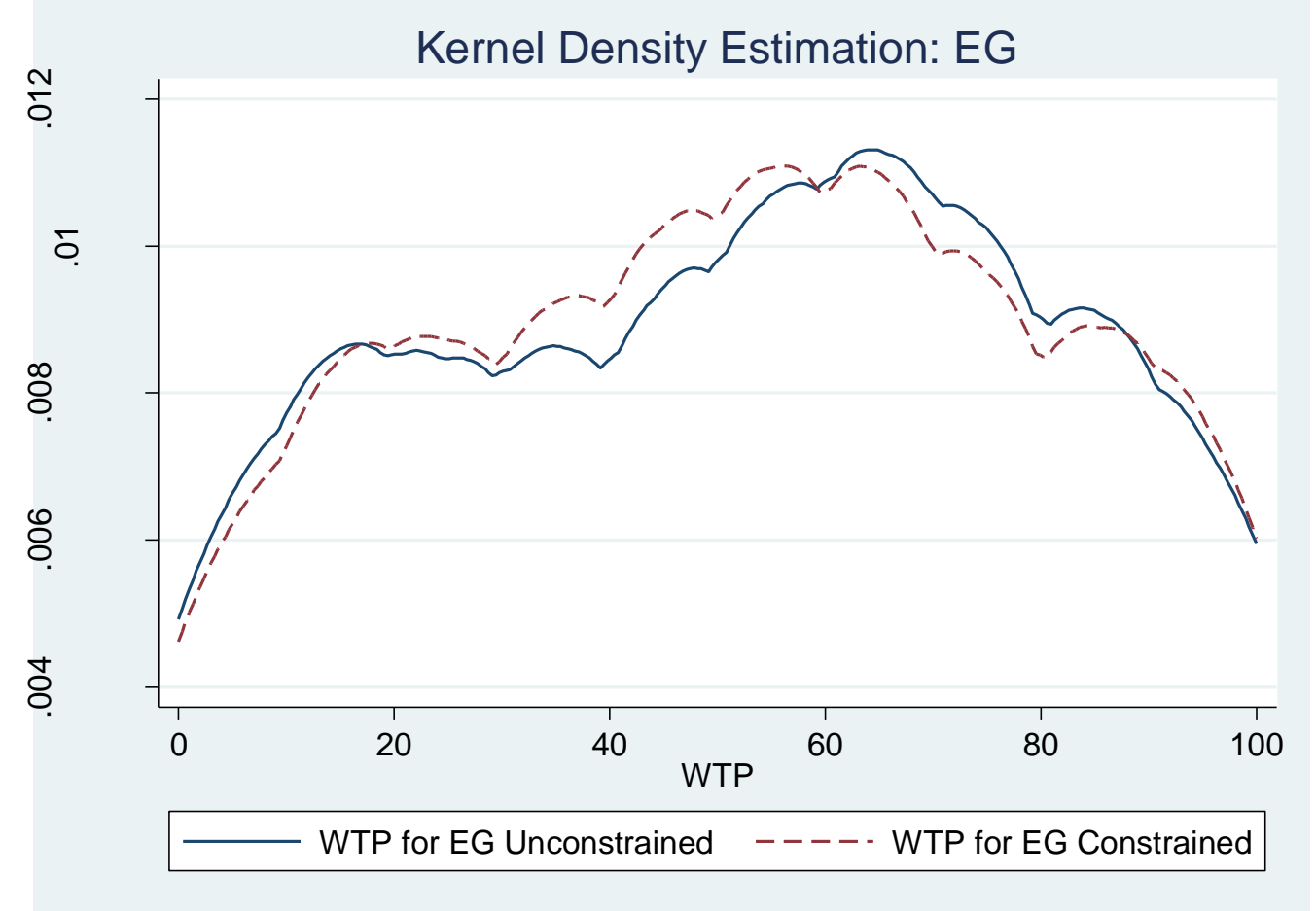

Overall, it appears that there is no difference between the WTP of unconstrained and constrained versions of the games. In other words, in these data, the initial hypothesis about control aversion was not confirmed.

However, looking at the subjects' behavior in individual games reveals interesting patterns. This analysis also confirms that our assumption of non-binding constraints was valid. First let's look at the subjects' behavior in DG. There were 38 cases where participants played a DG (constrained or unconstrained). In 9 out of 38 cases, the difference between the prices of DG unconstrained and DG constrained was positive (i.e. subjects' valuation for the game in which they had the freedom of choice was higher compared to their valuation of the constrained version of the game). The mean contribution for these 9 subjects was 27.44, and it was only 1 out of 9 cases in which someone gave beyond the constraint. If we exclude this one person, then giving for the 8 remaining subjects averages to $20.25 \%$ with minimum 0 and maximum 60 . From these data, the first 
fact one can conclude is that for these 8 people, the imposed constraint was not binding (i.e. was irrelevant). However, the interesting fact is that the mean difference between the prices of the unconstrained and constrained versions of DG was 44.5 ECU. Given the fact that the constraint was non-binding (i.e. the participants would not care for sending more than $70 \%$ of their endowment to charity in any way), such a big difference in valuations could be due to the subject experiencing a strong psychological reaction. In 20 cases out of 38 , the difference between the valuations of unconstrained and constrained versions of DG was zero. The average donation to charity in this case was $7.85 \%$ of the initial endowment, again confirming the assumption that the imposed constraint was nonbinding. In the remaining 9 cases, the difference between prices was negative. The average donation in this case was $6.4 \%$ of the endowment with a maximum of $20 \%$. In this case though, the participants valued the constrained version of the game 36.4 ECUs higher than the unconstrained one. The reason why participants valued a constrained version of the game more could be that these people were the most selfish (as confirmed by the average donation) who did not enjoy giving but also, once presented with opportunity, they would rather give because they do not like not giving (Lazear, Malmendier, \& Weber, 2011). Therefore, it could be the case that these people considered the prohibition as a moral excuse for not giving and thus valued the constrained game more. The LG was played on 41 occasions. In 18 cases, the difference between prices was positive. Out of these 18 cases, the average number where people chose a risky option was 3.38 with a maximum of 5 times. Therefore, we can conclude that for these people, the constraint (that said that they could not choose Option B in more than 7 cases) was not binding. The mean difference between prices was 16.25. Again something one cannot expect when it is clear that the constraint is non-binding, and this fact can indicate that the subjects experienced a psychological reactance. In 18 cases, the difference between 
valuations is zero. On this occasion, the subjects chose a risky option 4.72 times on average, a number which is way below the imposed constraint. In only 5 cases did subjects value the constrained version of LG more, and they chose a risky option 3 times on average with a maximum of 6 times. The average difference in valuations was 9.6 ECUs in favor of the constrained version. It could be that these were risk adverse subjects, and they valued the initial commitment of not choosing lots of risky options. Even though we observe that for some people freedom of choice matters, overall we cannot make such a claim because the observed data, with a high likelihood, seem to be the results of random behavior. A similar pattern of valuation differences is observed between the unconstrained and constrained versions of EG. There are people who value the unconstrained version more, seemingly due to reactance, but there are others who value the constrained version of the EG more, and the overall data are consistent with random behavior. One thing to notice though is that in all cases of EG, the subjects chose to switch from the math to the counting task after 45 seconds. That is, their behavior was consistent with the initial assumption that the productivities did not differ across tasks, and the subjects would allocate their time so as to maximize their total earnings from the two tasks.

This experiment does not document that control has any significant effect on individual behavior. There could be several reasons why in this experiment subjects did not exhibit reactance. The psychological literature implies that reactance is an emotional response, and it manifests itself while people experience anger or affection (Brehm, 1966). Therefore, it might be the case that while forcing subjects to think about the BDM value elicitation mechanism and dragging their conscience into a cognitively very demanding strategy method, they started to think more rationally and less emotionally. It could also be the case that when the experimenter is giving money to subjects, they might feel that the experimenter is also entitled to create the rules of the experiment. Thus, they 
may not feel motivated to rebel after all. One way to address this problem would be to let subjects earn money and eliminate the entitlement effect. Another possibility of why subjects did not display control aversion could be the method of communicating prohibition. Brehm (1966) argues that the extent of reactance is proportional to the degree of threat. In this experiment, the subjects read a prohibitive message on the computer screen and therefore lacking a specific source of authority, the threat of the message could have been low. If instead it was an experimenter who communicated message, then the perceived threat to freedom could have been higher.

\section{Conclusion}

This experimental study was the first step for bringing the theory of psychological reactance into economics and to document experimentally that people dislike control. In other words, this study tried to explore how people value freedom of choice. For this purpose, I designed an experiment in which subjects were asked to express their valuation of two- choice situations. In one case, subjects were given absolute freedom, whereas in another, the extent of their freedom of choice was limited. However, in order to measure control aversion solely, a limit was chosen so that in normal situations (i.e. without constraint), subjects would not pursue a set of behaviors beyond that limit. Even though it can be said that for some subjects the prohibition lowered their valuation of the game due to control aversion, the overall data did not confirm that subjects' valuation of free and limited choice situations differ significantly. Thus the initial hypothesis was not confirmed.

This study does not document that the forces of psychological reactance have an effect on individual behavior. However, as I have pointed out, it could be the case that subjects experienced reactance as they were forced to make rational decisions to the extent 
of reactance, which is a neat emotional trait, but it was diluted and did not show up in this particular experiment. It is also possible, that the constraint imposed in this experiment was not salient enough to induce reactance. 


\section{References}

Allingham, M. G., \& Sandmo, A. (1972). Income tax evasion: A theoretical analysis. Journal of Public Economics, 1 (3/4), 323-338.

Becker, G., DeGroot, M., \& Marschak, J. (1964). Measuring utility by a single-response sequential method. Behavioral Science, 9, 226-236.

Becker, G. S., \& Murphy K .M. (1988). A Theory of Rational Addiction. Journal of Political Economy, 96, 675-700.

Becker, G. S. (1968). Crime and Punishment: An Economic Approach. Journal of Political Economy, 76 (2), 169-217.

Brehm, J. W. (1966). A theory of psychological reactance. New York: Academic Press.

Brehm, J. W., \& Brehm, S. S. (1981). Psychological reactance: A theory of freedom and control. San Diego, CA: Academic Press.

Brehm, J. W., Stires, L. K., Sensenig, J., \& Shaban, J. (1966). The attractiveness of an eliminated choice alternative. Journal of Experimental Social Psychology, 2(3), 301313.

Bowles, S., \& Polania-Reyes, S. (2017). Economic incentives and social preferences: Substitutes or complements? Journal of Economic Literature, 50(2), 368-425.

Camerer, C. F. (2011). Behavioral game theory: Experiments in strategic interaction. New Jersey: Princeton University Press.

Darrow, C., \& Yarros, V. S. (1927). The prohibition mania: A reply to Professor Irving Fisher and others. New York: Boni and Liveright.

Dills, A. K., \& Miron, J. A. (2004). Alcohol prohibition and cirrhosis. American Law and Economics Review, 6(2), 285-318.

Ehrlich, I. (1973). Participation in illegitimate activities: A theoretical and empirical investigation. The Journal of Political Economy, 81 (3), 521-565. 
Fischbacher, U. (2007). z-Tree: Zurich toolbox for ready-made economic experiments. Experimental Economics, 10(2), 171-178.

Falk, A., \& Kosfeld, M. (2006). The hidden costs of control. The American Economic Review, 1611- 1630.

Fehr, E., \& Schmidt, K. M. (1999). A theory of fairness, competition, and cooperation. The Quarterly Journal Economics, 114(3), 817-868.

Ferdinand, T. N. (1967). The criminal patterns of Boston since 1849. American Journal of Sociology, 84-99.

Gneezy, U., \& Rustichini, A. (2000). Fine is a price. American Journal of Legal Studies, 29 (1), 1-18.

Hammock, T., \& Brehm, J. W. (1966). The attractiveness of choice alternatives when freedom to choose is eliminated by a social agent. Journal of Personality, 34, 546554.

Holt, C. A., \& Laury, S. K. (2002). Risk aversion and incentive effects. The American Economic Review, 92(5), 1644-1655.

Lazear, E. P., Malmendier, U., \& Weber, R. A. (2012). Sorting in experiments with application to social preferences. American Economic Journal: Applied Economics, 4(1), 136-163.

Mazis M. B. and Settle R. B. (1972). "Consumer Reaction to Restriction of Choice Alternatives", in Proceedings of the Third Annual Conference of the Association for Consumer Research : Association for Consumer Research, Pages: 417-427.

Mazis, M. B., Settle, R. B., \& Leslie, D. C. (1973). Elimination of phosphate detergents and psychological reactance. Journal of Marketing Research, 390-395.

Miron J.A., Zwiebel J., (1991). Alcohol consumption during Prohibition. American Economic Review: Papers and Proceedings, 81(2), 242-47. 
Miron, J. A., \& Zwiebel, J. (1995). The economic case against drug prohibition. The Journal of Economic Perspectives, 9(4), 175-192.

Polinsky, A. M., \& Shavell, S. (2007). The theory of public enforcement of law. Handbook of Law and Economics, 1, 403-454.

Schneider, F., \& Enste, D. (2000). Shadow economies around the world-size, causes, and Consequences. Journal of Economic Literature, 38, 77-114.

Slemrod, J., Blumenthal, M., \& Christian, C. (2001). Taxpayer response to an increased probability of audit: Evidence from a controlled experiment in Minnesota. Journal of Public Economics, 79(3), 455-483.

Spicer, M. W. (1974). A behavioral model of income tax evasion (Unpublished Doctoral dissertation). Ohio State University, Ohio, USA.

Thornton, M. (2007). The economics of prohibition. University of Utah Press: Salt Lake City.

Thornton, M. (1991). Alcohol prohibition was a failure. Policy Analysis, 157.

Tucker, C. (2011, May). Social Networks, Personalized Advertising, and Perceptions of Privacy Control. In Proceedings of the Tenth Workshop on the Economics of Information Security (WEIS).

Verhallen, T., M. \& Robben. H. S. (1994). Unavailability and the evaluation of goods. KYKLOS, 48 (3), 369-387.

Worchel, S., and Brehm, J. W. (1970). Effect of Threat to Attitudinal Freedom as a Function of Agreement with the Communicator. Journal of Personality and Social Psychology 14: 18-22.

Worchel, S., Lee, J., \& Adewole, A. (1975). Effects of supply and demand on ratings of object value. Journal of Personality and Social Psychology, 32(5), 906-914. 


\section{Appendix A}

Table A1 Holt and Laury lottery choice task

\begin{tabular}{|l|r|l|}
\hline \multicolumn{1}{|c|}{ Option A } & Option B & $\begin{array}{l}\text { pxpected } \\
\text { payoff } \\
\text { difference }\end{array}$ \\
\hline $1 / 10$ of $120 \mathrm{ECU}, 9 / 10$ of $96 \mathrm{ECU}$ & $1 / 10$ of $231 \mathrm{ECU}, 9 / 10$ of $6 \mathrm{ECU}$ & $70.2 \mathrm{ECU}$ \\
\hline 2/10 of $120 \mathrm{ECU}, 8 / 10$ of $96 \mathrm{ECU}$ & $2 / 10$ of $231 \mathrm{ECU}, 8 / 10$ of $6 \mathrm{ECU}$ & $49.8 \mathrm{ECU}$ \\
$4 / 10$ of $120 \mathrm{ECU}, 7 / 10$ of $96 \mathrm{ECU}$ & $3 / 10$ of $231 \mathrm{ECU}, 7 / 10$ of $6 \mathrm{ECU}$ & $30 \mathrm{ECU}$ \\
$5 / 10$ of $120 \mathrm{ECU}, 6 / 10$ of $96 \mathrm{ECU}$ & $4 / 10$ of $231 \mathrm{ECU}, 6 / 10$ of $6 \mathrm{ECU}$ & $9.6 \mathrm{ECU}$ \\
$6 / 10$ of $120 \mathrm{ECU}, 4 / 10$ of $96 \mathrm{ECU}$ & $6 / 10$ of $231 \mathrm{ECU}, 4 / 10$ of $6 \mathrm{ECU}$ & $-30.6 \mathrm{ECU}$ \\
$7 / 10$ of $120 \mathrm{ECU}, 3 / 10$ of $96 \mathrm{ECU}$ & $7 / 10$ of $231 \mathrm{ECU}, 3 / 10$ of $6 \mathrm{ECU}$ & $-51 \mathrm{ECU}$ \\
$8 / 10$ of $120 \mathrm{ECU}, 2 / 10$ of $96 \mathrm{ECU}$ & $8 / 10$ of $231 \mathrm{ECU}, 2 / 10$ of $6 \mathrm{ECU}$ & $-70.8 \mathrm{ECU}$ \\
$9 / 10$ of $120 \mathrm{ECU}, 1 / 10$ of $96 \mathrm{ECU}$ & $9 / 10$ of $231 \mathrm{ECU}, 1 / 10$ of $6 \mathrm{ECU}$ & $-91.2 \mathrm{ECU}$ \\
$10 / 10$ of $120 \mathrm{ECU}, 0 / 10$ of $96 \mathrm{ECU}$ & $10 / 10$ of $231 \mathrm{ECU}, 0 / 10$ of $6 \mathrm{ECU}$ & $-111 \mathrm{ECU}$ \\
\hline
\end{tabular}

Table A2 Effort game payoff structure.

\begin{tabular}{|ll|lr|}
\hline \multicolumn{2}{|c|}{ Exercise "math" } & \multicolumn{2}{c|}{ Exercise "counting zeros" } \\
\hline $0-15$ seconds & $8 \mathrm{ECU}$ & $0-15$ seconds & $8 \mathrm{ECU}$ \\
$15-30$ seconds & $6 \mathrm{ECU}$ & $15-30$ seconds & $6 \mathrm{ECU}$ \\
$30-45$ seconds & $2 \mathrm{ECU}$ & $30-45$ seconds & $4 \mathrm{ECU}$ \\
$45-60$ seconds & $0 \mathrm{ECU}$ & $45-60$ seconds & $2 \mathrm{ECU}$ \\
& & & \\
\hline
\end{tabular}




\section{Appendix C}

\section{Supplementary material}

\section{Instructions}

Welcome to our experiment.

This is an experiment in the economics of decision-making.

The instructions are simple, and if you follow them carefully and make good decisions, you might earn a considerable amount of money. Different participants may earn different amounts. Your payoff and the payoff of other participants in this experiment will be measured in Experimental Currency Units (ECU). Throughout the experiment, all values are stated in ECUs as well. At the end of the experiment, the experimental units you earned will be converted into a cash payoff in $\mathbf{C Z K}$ using the exchange rate $\mathbf{1 E C U}=\mathbf{2 . 5} \mathbf{C Z K}$. Average earnings in this experiment will be $\mathbf{4 0 0}$ CZK. Your cash payoff will be rounded up to the next nearest $10 \mathrm{CZK}$. You will be paid in cash privately at the end of the experiment. The accountant who is in charge of the payment is not a member of the research team and has not been informed about the details of the experiment. Therefore s/he cannot infer your behavior in the experiment from your earnings. Also s/he will not disclose the amount you will earn to the experimenters. Therefore none of the experimenters will be able to match your personal decisions to your identity. Your decisions in this experiment will remain absolutely confidential.

The experiment will take place through the computer terminals at which you are seated. It is important that you keep your eyes on your own screen. During the experiment, please do not communicate with other participants. Please turn off your mobile phone at this time. If you have a question, please raise your hand and one of the experimenters will assist you.

A pen and a note sheet are prepared for you on your desk in case you want to use them. 


\section{Procedure}

In this experiment you are given an initial amount of $\mathbf{1 0 0}$ experimental currency units (ECUs).

The experiment consists of two stages:

\section{STAGE 1}

In the first stage, you will be presented with six games: G1, G2, G3, G4, G5, and G6. Later in the second stage, the computer program will randomly choose one of these six games that you might play. It is equally likely that any of these six games will be chosen. You can earn additional ECUs by playing the game.

In order to play the selected game, you need to pay any amount from $\mathbf{0}$ to $100 \mathrm{ECU}$. Below, we shall explain in detail how the payment process works.

First of all, you will be asked how much from $\mathbf{0}$ to $\mathbf{1 0 0}$ ECU you are willing to pay to be able to play any of the six games. After you state your willingness to pay (P), the computer randomly draws a number $(\mathbf{N})$ from $\mathbf{0}$ to $\mathbf{1 0 0}$.

If your stated willingness to pay for the selected game is greater than or equal to the randomly drawn number by the computer (that is $\mathbf{P} \geq \mathbf{N}$ ), then you obtain the right to play the selected game, and you need to pay $\mathbf{N}$ ECU for it - not your stated willingness to pay (P). In the second stage, you make a decision in the selected game, and the amount of $\mathbf{N}$ ECU will be deducted from your final payoff. 
If your stated willingness to pay for the selected game is strictly less than the randomly drawn number (that is $\mathbf{P}<\mathbf{N}$ ), then you will not obtain the right to play the selected game in the second stage, and you keep 100 ECU.

To clarify, consider the following example. If your stated willingness to pay for a particular game is $60 \mathrm{ECU}(\mathbf{P})$ and the randomly drawn number is $\mathbf{1 5}(\mathbf{N})$, then, if this game is selected, you will play the game (because $\mathbf{P}>\mathbf{N}$ ) and 15 ECU (N) will be deducted from your final payoff.

If your stated willingness to pay for a game is $60 \mathrm{ECU}(\mathbf{P})$ and the randomly drawn number is $\mathbf{8 0}(\mathbf{N})$, then, if this game is selected, you will not play the game (because $\mathbf{P}<\mathbf{N}$ ), you will not pay anything and you keep 100 ECU.

Please note that any numbers used in the examples above are for illustrative purposes only. They are not supposed to be suggestive of anyone's actual behavior in this experiment.

Given the mechanism of the payment procedure, it is in your best interest to state your true willingness to pay to play the given game. That is, given your true willingness to pay for the game, you will never do better than stating it truthfully. We ask you to take this for granted for now, and in case there are any further questions the experimenter will be happy to explain this in more detail after the experiment. 


\section{STAGE 2}

As stated earlier, in the second stage the computer will randomly select one game out of G1, G2, G3, G4, G5, and G6. Each game has an equal chance of being selected. Call this game $\mathbf{G}$. Then the computer will randomly draw a number $(\mathbf{N})$ from $\mathbf{0}$ to $\mathbf{1 0 0 .}$

\section{Case 1: $\mathbf{P} \geq \mathbf{N}$}

If your stated willingness to pay (P) for $\mathrm{G}$ is greater or equal to $\mathbf{N}$, then you will play $\mathbf{G}$ and pay $\mathbf{N}$ ECU.

Your Payoff = Initial Amount $(\mathbf{1 0 0}$ ECU $)-$ Number drawn by the computer $(\mathbf{N})+$ Earnings from $\mathbf{G}$.

\section{Case 2: $\mathbf{P}<\mathbf{N}$}

If your stated willingness to pay (P) for $\mathrm{G}$ is lower than $\mathbf{N}$, then you will not play the game.

Your payoff = Initial Amount $(100 \mathrm{ECU})$. 


\section{Further Information}

The remaining instructions in this experiment will be shown on your screen. You will have these printed instructions at hand during the entire experiment, so you can refer to them at any time you wish.

Please wait until the Instruction Stage is over. When asked, press the "START THE EXPERIMENT" button that will show up on your screen. 


\section{Working Paper Series}

ISSN 1211-3298

Registration No. (Ministry of Culture): E 19443

Individual researchers, as well as the on-line and printed versions of the CERGE-EI Working Papers (including their dissemination) were supported from institutional support RVO 67985998 from Economics Institute of the ASCR, v. v. i.

Specific research support and/or other grants the researchers/publications benefited from are acknowledged at the beginning of the Paper.

(c) Lasha Lanchava, 2013

All rights reserved. No part of this publication may be reproduced, stored in a retrieval system or transmitted in any form or by any means, electronic, mechanical or photocopying, recording, or otherwise without the prior permission of the publisher.

Published by

Charles University in Prague, Center for Economic Research and Graduate Education (CERGE) and

Economics Institute of the ASCR, v. v. i. (EI)

CERGE-El, Politických vězňů 7, 11121 Prague 1, tel.: +420 224005 153, Czech Republic.

Printed by CERGE-EI, Prague

Subscription: CERGE-EI homepage: http://www.cerge-ei.cz

Phone: + 420224005153

Email: office@cerge-ei.cz

Web: http://www.cerge-ei.cz

Editor: Michal Kejak

The paper is available online at http://www.cerge-ei.cz/publications/working_papers/.

ISBN 978-80-7343-296-6 (Univerzita Karlova. Centrum pro ekonomický výzkum a doktorské studium)

ISBN 978-80-7344-288-0 (Národohospodářský ústav AV ČR, v. v. i.) 
CERGE-EI

P.O.BOX 882

Politických vězňů 7

11121 Praha 1

Czech Republic http://www.cerge-ei.cz 